\title{
EFEKTIVITAS JAMUR Beauveria bassiana DAN POC KEONG MAS TERHADAP KERUSAKAN TANAMAN DAN HASIL TERUNG VARIETAS LAGUNA F1
}

\section{(Effectiveness Of Beauveria Bassiana And Golden Snail Lof On Plant Damage And Yield Of Eggplant Of Laguna F1 Variety)}

\author{
Erwin Arief Rochyat ${ }^{1}$, Karno ${ }^{1}$, Candra Catur Nugroho ${ }^{1}$, dan Kartika Dewi Ramadhani ${ }^{2}$ \\ ${ }^{1)}$ Dosen Prodi Agroteknologi, Faperta Universitas Kutai Kartanegara \\ ${ }^{2)}$ Alumni Prodi Agroteknologi, Faperta Universitas Kutai Kartanegara \\ Penulis koresponden: candracatur@unikarta.ac.id
}

Article Submitted: 24-08-2021

Article Accepted: 05-01-2022

\begin{abstract}
This research was aimed to determine the effect of Beauveria bassiana and golden snail liquid organic fertilizer (LOF) and their interaction on plant damage and yield of eggplant of Laguna F1 variety. This research was arranged by Randomized Block Design (RBD) with 3 x 3 factorial analysis with three replications. $1^{\text {st }}$ factor was the application of Beauveria bassiana (B) consisting of 3 levels, i.e. $b_{0}$ (control or no treatment), $b_{1}\left(20 \mathrm{~g}\right.$ Beauveria bassiana $\mathrm{L}^{-1}$ water), and $\mathrm{b}_{2}$ (40 g Beauveria bassiana $\mathrm{L}^{-1}$ water). $2^{\text {nd }}$ factor was the application of golden snail LOF (P) consisting of 3 levels, i.e. $\mathrm{p}_{0}$ (control or no treatment), $\mathrm{p}_{1}\left(21 \mathrm{ml} \mathrm{LOF} \mathrm{L^{-1 }}\right.$ water), and $\mathrm{p}_{2}(42$ $\mathrm{ml} \mathrm{LOF} \mathrm{\textrm {L } ^ { - 1 }}$ water). The results showed that the application of Beauveria bassiana and golden snail LOF and their interactions hadn't significant effect on all parameters. The highest average yield per hectare $\left(\mathrm{t} \mathrm{ha}^{-1}\right)$ was obtained in treatment $\mathrm{b}_{2}\left(40 \mathrm{~g}\right.$ Beauveria bassiana $\mathrm{L}^{-1}$ water) which was $13.62 \mathrm{t} \mathrm{ha}^{-1}, \mathrm{p}_{2}\left(42 \mathrm{ml} \mathrm{LOF} \mathrm{L}{ }^{-1}\right.$ water $)$ was $14.27 \mathrm{t} \mathrm{ha}^{-1}$, and the treatment combination $\mathrm{b}_{1} \mathrm{p}_{2}$ (20 g Beauveria bassiana $\mathrm{L}^{-1}$ water and $42 \mathrm{ml} \mathrm{LOF} \mathrm{L}^{-1}$ water) was $15.07 \mathrm{t} \mathrm{ha}^{-1}$. Meanwhile, the lowest intensity of plant damage was obtained in treatment $\mathrm{b}_{2}\left(40 \mathrm{~g}\right.$ Beauveria bassiana $\mathrm{L}^{-1}$ water) which was $13.33 \%, \mathrm{p}_{2}\left(42 \mathrm{ml} \mathrm{LOF} \mathrm{L}^{-1}\right.$ water) was $15.56 \%$, and treatment combination $\mathrm{b}_{1} \mathrm{p}_{2}\left(20 \mathrm{~g}\right.$ Beauveria bassiana $\mathrm{L}^{-1}$ water and $42 \mathrm{ml} \mathrm{LOF} \mathrm{L}^{-1}$ water) was $8.33 \%$.
\end{abstract}

Keywords: Beauveria bassiana, golden snail liquid organic fertilizer, eggplant

\section{PENDAHULUAN}

Tanaman terung (Solanum melongena L.) merupakan salah satu jenis sayuran buah yang penting dan memiliki banyak varietas dengan beragam bentuk dan warna. Setiap varietas memiliki penampilan morfologi dan citra rasa yang berbeda. Buah terung banyak disukai masyarakat dan banyak diolah menjadi sayuran seperti sayur opor, lodeh, tumis atau lalap mentah.

Dinas Pertanian dan Peternakan Kabupaten Kutai Kartanegara melaporkan bahwa pada tahun 2018 luas panen terung di Kutai Kartanegara adalah 448 ha, dengan jumlah produksi 5.037,9 $\mathrm{t}$ dan produktivitas sebesar 11,25 $\mathrm{t} \mathrm{ha}^{-1}$, sedangkan pada tahun 2019 dengan luas panen 509 ha dan produktivitas $9,67 \mathrm{t}^{-1} \mathrm{~h}^{-1}$ mampu memproduksi terung sebesar $4.922 \mathrm{t}$. Berdasarkan informasi tersebut, terjadi penurunan produksi dan produktivitas tanaman terung (Dinas Pertanian dan Peternakan Kabupaten Kutai Kartanegara, 2020).

Banyak faktor yang mempengaruhi dalam budidaya tanaman terung diantaranya yaitu iklim, kesuburan tanah, penyediaan bahan tanam, maupun teknis budidaya. Bahan tanaman yang berkualitas baik akan 
memberikan produksi dan produktivitas tanaman yang baik pula (Cahyono, 2016). Selain itu, untuk mendapatkan pertumbuhan tanaman yang baik diperlukan media tanam yang memiliki kecukupan unsur hara yang harus selalu tersedia. Oleh sebab itu, pemberian pupuk perlu dilakukan untuk menjaga ketersediaan unsur hara dalam tanah. Pemupukan bertujuan untuk menjamin kecukupan dan keseimbangan hara tanaman sehingga pertumbuhan tanaman menjadi lebih baik. Pemupukan dapat dilakukan dengan pemberian pupuk organik maupun pupuk anorganik. Pupuk organik ada 2 jenis berdasarkan bentuknya yaitu pupuk organik padat dan pupuk organik cair. Salah satu pupuk organik cair (POC) yang bisa dimanfaatkan adalah POC keong mas. Banyak penelitian yang telah memanfaatkan POC keong mas ini untuk menunjang pertumbuhan dan perkembangan tanaman (Asrah dan Novriani, 2019; Poerba, dkk., 2019; Nugroho, dkk., 2020; Ngadiani, dkk., 2021).

Selain penggunaan POC, teknologi Pengendalian Hama Terpadu (PHT) pada tanaman terung juga perlu diperhatikan. Teknologi PHT secara hayati dapat dimanfaatkan karena relatif aman akan tetapi cara kerjanya lebih lama untuk membunuh serangga dibandingkan dengan cara kimia yang dapat langsung membunuh hama (Sembel et al., 2007). Alternatif pengendalian yang dapat digunakan yaitu salah satunya dengan patogen serangga. Beauveria bassiana merupakan salah satu musuh alami berbentuk jamur entomopatogen yang menjadi bagian dari PHT. Efektivitas Beauveria bassiana sebagai pengendali sejumlah hama serangga sudah banyak dibuktikan melalui berbagai penelitian, efektivitas yang dimaksud yaitu mampu mengurangi populasi hama serangga (kutu kebul, belalang, dan lalat buah) yang merusak tanaman budidaya (Sheeba et al., 2001; Townsend et al., 2003; Bednarek et al., 2004; Thungrabeab and Tongma, 2007).

Berdasarkan uraian di atas, maka perlu dilakukan penelitian tentang pengaruh jamur Beauveria bassiana dan POC keong mas serta interaksinya terhadap kerusakan tanaman dan hasil terung (Solanum melongena L.). Penelitian ini bertujuan untuk mengetahui pengaruh jamur Beauveria bassiana dan POC keong mas serta interaksinya terhadap kerusakan tanaman dan hasil terung.

\section{METODE PENELITIAN}

\section{Waktu dan Tempat}

Penelitian ini dilaksanakan pada bulan September sampai Desember 2019. Lokasi penelitian bertempat di Kelurahan Bukit Biru, Kecamatan Tenggarong, Kabupaten Kutai Kartanegara.

\section{Bahan dan Alat}

Bahan yang digunakan dalam penelitian ini adalah benih terung varietas Laguna F1, jamur Beauveria bassiana powder, POC keong mas, pupuk kandang ayam, dan mulsa hitam perak. Alat yang digunakan adalah cangkul, lingga, potray, paranet $50 \%$, sprayer, gunting, kamera, alat ukur (meteran), timbangan analitik, gembor, dan alat tulis.

\section{Rancangan Penelitian}

Rancangan yang digunakan dalam penelitian ini adalah rancangan acak kelompok (RAK) faktorial terdiri atas dua faktor dengan 3 ulangan. Faktor pertama adalah pemberian Beauveria bassiana (B) uang terdiri atas 3 taraf yaitu $b_{0}=$ kontrol, $b_{1}=20$ g Beauveria bassiana $\mathrm{l}^{-1}$ air, dan $\mathrm{b}_{2}=40 \mathrm{~g}$ Beauveria bassiana $1^{-1}$ air. Faktor kedua adalah pemberian pupuk organik cair keong mas yang terdiri atas 3 taraf yaitu $\mathrm{p}_{0}=$ kontrol, $\mathrm{p}_{1}=21$ $\mathrm{ml} \mathrm{POC} 1^{-1}$ air, dan $\mathrm{p}_{2}=42 \mathrm{ml} \mathrm{POC} \mathrm{l}^{-1}$ air.

\section{Pelaksanaan Penelitian}

1. Persiapan lahan

Pertama-tama lahan penelitian dibersihkan dari gulma menggunakan cangkul dan lingga. Setelah bersih, lahan kemudian digemburkan dengan menggunakan cangkul (kedalaman $\pm 20 \mathrm{~cm}$ ), diberi pupuk kandang ayam sebanyak 2 ton $\mathrm{ha}^{-1}$ lalu diratakan selanjutnya dicangkul kembali. Pengolahan lahan bertujuan untuk menghilangkan tanaman pengganggu, menggemburkan tanah, dan 
membuat sistem penyerapan air yang baik. Lahan yang telah selesai diolah kemudian dibuat 3 kelompok sebagai ulangan yang selanjutnya dibagi menjadi 9 petak per kelompok dengan ukuran petak (240 x 240) $\mathrm{cm}$, tinggi petak $\pm 20 \mathrm{~cm}$, jarak antar petak dalam ulangan $50 \mathrm{~cm}$ dan jarak antar ulangan $100 \mathrm{~cm}$. Lahan yang sudah diolah dibiarkan selama 2 minggu sebelum ditanami. Lahan tersebut ditutup dengan mulsa hitam perak.

2. Persemaian benih terung

Benih terung disemai terlebih dahulu di potray ukuran 120 lubang. Media semai yang digunakan adalah campuran pupuk kandang ayam dan lapisan tanah atas (top soil) dengan perbandingan 1 : 1 . Benih terung sebelum disemai dilakukan seleksi benih terlebih dahulu dengan cara merendam benih dalam air hangat selama 10 menit. Benih yang baik akan tenggelam, sedangkan benih yang jelek atau keriput akan mengambang. Benih yang sudah siap selanjutnya disemai pada potray, tiap lubang potray berisi dua benih yang kemudian diletakkan di tempat yang ternaungi paranet $50 \%$. Penyiraman benih dengan menggunakan hand sprayer dilakukan pada pagi dan sore hari.

3. Penanaman

Penanaman dilakukan setelah bibit terung berumur 30 hari setelah semai. Bibit terung hasil persemaian dilakukan pengelompakan berdasarkan kemiringan lahan yaitu kelompok I (bagian atas), kelompok II (bagian tengah) dan kelompok III (bagian bawah). Selanjutnya, bibit dipindahkan ke petakan lahan percobaan satu lubang satu bibit terung. Satu petakan ditanami 16 bibit terung yang berjarak tanam $(60 \times 60) \mathrm{cm}$.

4. Pemeliharaan

a. Penyulaman

Dilakukan pada saat tanaman berumur tujuh (7) hari setalah dipindahkan ke lahan terhadap tanaman yang mati atau tidak tumbuh dengan cara mengganti bibit cadangan yang tumbuh pada potray hasil persemaian sebelumnya. Saat penelitian dilakukan penyulaman pada ulangan 1 petak $b_{0} p_{0}$, ulangan 1 petak $b_{0} p_{2}$, ulangan 2 petak $b_{1} p_{0}$, dan ulangan 3 petak $b_{0} p_{2}$.

b. Penyiraman

Penyiraman dilakukan pada pagi hari dan sore hari atau disesuaikan dengan kondisi di lapangan. Penyiraman dilakukan dengan menggunakan gembor yang diisi air (10 liter petak $^{-1}$ ) yang kemudian disiramkan ke setiap tanaman di lahan hingga basah.

c. Penyiangan gulma

Dilakukan penyiangan gulma dengan membersihkan gulma yang tumbuh disekitar tanaman dan petakan lahan. Penyiangan dilakukan setiap bulan atau ketika pertumbuhan gulma sudah mengganggu pertumbuhan tanaman terung. Pengendalian dilakukan dengan cara mencabut gulma dengan tangan atau dibantu dengan lingga.

d. Pengendalian hama dan penyakit

Selama penelitian berlangsung, ditemukan beberapa hama yaitu ulat grayak, kutu kebul, dan lalat buah. Penyakit yang menyerang yaitu bercak daun dan busuk buah. Pada penelitian tidak dilakukan pengendalian hama dan penyakit dikarenakan salah satu faktor perlakuan menggunakan agen hayati jamur Beauveria bassiana untuk melihat pengaruhnya terkait intensitas kerusakan tanaman akibat serangan hama dan penyakit..Penanaman

5. Pemberian Beauveria bassiana dan POC

Beauveria bassiana diberikan pada setiap tanaman sesuai perlakuan masing-masing. Pemberiannya dengan cara disemprotkan keseluruh bagian tanaman. Penyemprotan dilakukan setiap dua minggu sekali yaitu pada umur 20, 34, dan 48 hari setelah tanam. Sementara itu, POC keong mas diberikan pada setiap tanaman sesuai perlakuan masingmasing dengan cara disiramkan ke tanah di sekitar tanaman. Penyiraman dilakukan setiap minggu yaitu pada umur 20, 27, 34, 41, dan 48 hari setelah tanam.

6. Pemanenan 
Penentuan waktu dan cara panen menjadi faktor yang sangat penting untuk diperhatikan. Panen pertama buah terung pada peneilitian ini dilakukan saat umur 57 hari setelah tanam. Ciri-ciri panen yaitu buah masih muda dan kondisi buah masih tampak segar, kelihatan mengkilap, dan tidak berkeriput. Pemetikan buah menggunakan gunting, tangkai buah dipotong agak panjang. Panen dilakukan sebanyak 4 kali, dengan interval waktu panen 5 hari sekali (produksi menunjukkan trend menurun).

\section{Parameter Pengamatan}

Parameter pengamatan dilakukan untuk melihat pengaruh dari perlakuan yang diberikan. Parameter yang diambil sebagai data pengamatan sebagai berikut:

1. Jumlah buah per tanaman (buah)
Jumlah buah per tanaman ditentukan dengan cara menghitung jumlah buah per tanaman sampel sejak panen pertama hingga panen ke empat (terakhir).

2. Bobot per buah $(\mathrm{g})$

Bobot buah dihitung dengan cara menimbang bobot buah yang dipanen dibagi dengan jumlah buah dari tanaman sampel.

3. Hasil per tanaman $(\mathrm{kg})$

Hasil per tanaman dihitung dengan cara menimbang seluruh buah setiap tanaman sampel yang dipanen sejak panen pertama hingga panen ke empat.

4. Hasil produksi per hektar $\left(\mathrm{t} \mathrm{ha}^{-1}\right)$

Hasil produksi per ha diperoleh dengan cara menimbang bobot buah terung semua tanaman dari suatu petak perlakuan, kemudian dikonversikan ke dalam satuan $\mathrm{t} \mathrm{ha}^{-1}$ dengan menggunakan rumus:

$$
\text { Rumus tha }{ }^{-1}=\frac{\text { Luas } 1 \mathrm{ha}\left(\mathrm{m}^{2}\right)}{\text { Luas petak hasil }\left(\mathrm{m}^{2}\right)} \times \frac{\text { Hasil petak }^{-1}(\mathrm{~kg})}{1000(\mathrm{~kg})} \times 1 \mathrm{tha}^{-1}
$$

5. Intensitas kerusakan tanaman (\%)

Pengamatan ini dilakukan satu kali pada saat tanaman memasuki fase menjelang panen pertama. Pengamatan ini dilakukan untuk mengecek adanya hama serangga atau penyakit menyerang atau tidak sehingga bisa diketahui kerusakannya. Menurut Sastrosiwojo (1995), intensitas serangan dihitung menggunakan rumus berikut:

$\mathrm{I}=\frac{\sum\left(\mathrm{n}_{\mathrm{i}} \times \mathrm{v}_{\mathrm{i}}\right)}{\mathrm{Z} \times \mathrm{N}} \times 100 \%$

Keterangan:

I = intensitas kerusakan tanaman (\%)

$\mathrm{n}_{\mathrm{i}}=$ banyaknya tanaman atau bagian tanaman yang terserang pada skor ke-i

$\mathrm{v}_{\mathrm{i}}=$ nilai skor ke-i; nilai skor kerusakan bertahap yaitu:

0 = tidak ada kerusakaan sama sekali

1 = tingkat kerusakan daun $>0-\leq 20 \%$

2 = tingkat kerusakan daun $>20-\leq 40 \%$

3 = tingkat kerusakan daun $>40-\leq 60 \%$

4 = tingkat kerusakan daun $>60-\leq 80 \%$
5 = tingkat kerusakan daun $>80 \%$

$\mathrm{N}$ = banyaknya tanaman atau bagian tanaman sampel yang diamati

$\mathrm{Z}=$ skor tertinggi

\section{Analisis Data}

Data yang terkumpul kemudian dianalisis dengan uji $\mathrm{F}$ taraf 5\% Jika hasil uji $\mathrm{F}$ menunjukan adanya pengaruh nyata atau sangat nyata, maka dilanjutkan dengan Uji Beda Nyata Jujur (BNJ) taraf $\alpha=5 \%$.

\section{HASIL DAN PEMBAHASAN}

\section{Pengaruh Beauveria bassiana Jumlah Buah per Tanaman (buah)}

Hasil analisis menunjukkan bahwa pemberian Beauveria bassiana dan POC keong mas serta interaksinya memberikan pengaruh tidak nyata terhadap rata-rata jumlah buah per tanaman. Hasil pengamatan jumlah buah per tanaman disajikan pada tabel 1 . 
Tabel 1. Pengaruh Beauveria bassiana dan pupuk organik cair keong mas terhadap rata-rata jumlah buah per tanaman (buah)

\begin{tabular}{ccccc}
\hline \multirow{2}{*}{$\begin{array}{c}\text { Beauveria bassiana } \\
(\mathrm{b})\end{array}$} & $\mathrm{p}_{0}$ & $\mathrm{p}_{1}$ & $\mathrm{p}_{2}$ & Rata-rata \\
\cline { 2 - 5 } $\mathrm{b}_{0}$ & 4,08 & 4,42 & 4,25 & 4,25 \\
$\mathrm{~b}_{1}$ & 4,17 & 4,25 & 4,83 & 4,42 \\
$\mathrm{~b}_{2}$ & 4,42 & 4,50 & 4,58 & 4,50 \\
\hline Rata-rata & 4,22 & 4,39 & 4,56 & \\
\hline
\end{tabular}

Keterangan: $\mathrm{b}_{0}=$ kontrol, $\mathrm{b}_{1}=20 \mathrm{~g}$ Beauveria bassiana $\mathrm{l}^{-1}$ air, $\mathrm{b}_{2}=40 \mathrm{~g}$ Beauveria bassiana $\mathrm{l}^{-1}$

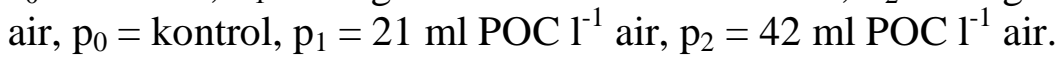

\section{Bobot per Buah (g)}

Hasil analisis menunjukkan bahwa pemberian Beauveria bassiana dan POC keong mas serta interaksinya memberikan pengaruh tidak nyata terhadap rata-rata bobot per buah. Hasil pengamatan bobot per buah disajikan pada tabel 2.

Tabel 2. Pengaruh Beauveria bassiana dan pupuk organik cair keong mas terhadap rata-rata bobot per buah $(\mathrm{g})$

\begin{tabular}{ccccc}
\hline Beauveria bassiana & \multicolumn{4}{c}{ POC keong mas $(\mathrm{p})$} \\
\cline { 2 - 5 }$(\mathrm{b})$ & $\mathrm{p}_{0}$ & $\mathrm{p}_{1}$ & $\mathrm{p}_{2}$ & Rata-rata \\
\hline $\mathrm{b}_{0}$ & 103,05 & 111,50 & 110,24 & 108,26 \\
$\mathrm{~b}_{1}$ & 98,70 & 102,96 & 111,86 & 104,51 \\
$\mathrm{~b}_{2}$ & 102,84 & 109,29 & 112,80 & 108,31 \\
\hline Rata-rata & 101,53 & 107,92 & 111,63 &
\end{tabular}

Keterangan: $\mathrm{b}_{0}=$ kontrol, $\mathrm{b}_{1}=20 \mathrm{~g}$ Beauveria bassiana $\mathrm{l}^{-1}$ air, $\mathrm{b}_{2}=40 \mathrm{~g}$ Beauveria bassiana $\mathrm{l}^{-1}$

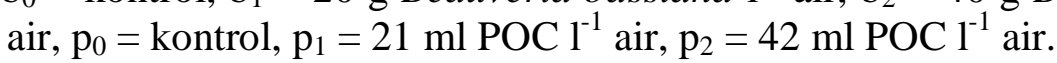

\section{Hasil per Tanaman $(\mathrm{kg})$}

Hasil analisis menunjukkan bahwa pemberian Beauveria bassiana dan POC keong mas serta interaksinya memberikan pengaruh tidak nyata terhadap rata-rata hasil per tanaman. Hasil pengamatan hasil per tanaman disajikan pada tabel 3.

Tabel 3. Pengaruh Beauveria bassiana dan pupuk organik cair keong mas terhadap rata-rata hasil per tanaman $(\mathrm{kg})$

\begin{tabular}{ccccc}
\hline Beauveria bassiana & \multicolumn{4}{c}{ POC keong mas $(\mathrm{p})$} \\
\cline { 2 - 5 }$(\mathrm{b})$ & $\mathrm{p}_{0}$ & $\mathrm{p}_{1}$ & $\mathrm{p}_{2}$ & Rata-rata \\
\hline $\mathrm{b}_{0}$ & 0,42 & 0,50 & 0,48 & 0,47 \\
$\mathrm{~b}_{1}$ & 0,43 & 0,48 & 0,54 & 0,49 \\
$\mathrm{~b}_{2}$ & 0,45 & 0,50 & 0,52 & 0,49 \\
\hline Rata-rata & 0,44 & 0,50 & 0,51 & \\
\hline
\end{tabular}

Keterangan: $\mathrm{b}_{0}=$ kontrol, $\mathrm{b}_{1}=20 \mathrm{~g}$ Beauveria bassiana $\mathrm{1}^{-1}$ air, $\mathrm{b}_{2}=40 \mathrm{~g}$ Beauveria bassiana $\mathrm{l}^{-1}$

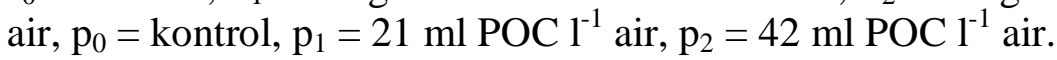


Hasil Produksi per Hektar (t ha $\left.{ }^{-1}\right)$ pemberian Beauveria bassiana dan POC keong mas serta interaksinya memberikan pengaruh tidak nyata terhadap rata-rata hasil produksi per hektar. Hasil pengamatan hasil hasil produksi per hektar disajikan pada tabel 4.

Tabel 4. Pengaruh Beauveria bassiana dan pupuk organik cair keong mas terhadap rata-rata hasil produksi per hektar $\left(\mathrm{t} \mathrm{ha}^{-1}\right)$

\begin{tabular}{ccccc}
\hline Beauveria & \multicolumn{4}{c}{ POC keong mas $(\mathrm{p})$} \\
\cline { 2 - 5 } bassiana $(\mathrm{b})$ & $\mathrm{p}_{0}$ & $\mathrm{p}_{1}$ & $\mathrm{p}_{2}$ & Rata-rata \\
\hline $\mathrm{b}_{0}$ & 11,66 & 13,97 & 13,29 & 12,98 \\
$\mathrm{~b}_{1}$ & 11,56 & 12,47 & 15,07 & 13,04 \\
$\mathrm{~b}_{2}$ & 12,54 & 13,85 & 14,46 & 13,62 \\
\hline Rata-rata & 11,92 & 13,43 & 14,27 & \\
\hline
\end{tabular}

Keterangan: $\mathrm{b}_{0}=$ kontrol, $\mathrm{b}_{1}=20 \mathrm{~g}$ Beauveria bassiana $\mathrm{l}^{-1}$ air, $\mathrm{b}_{2}=40 \mathrm{~g}$ Beauveria bassiana $\mathrm{l}^{-1}$

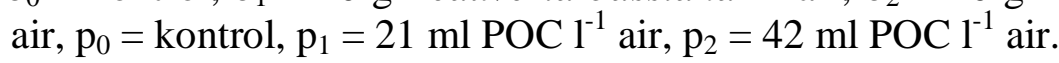

Intensitas Kerusakan Tanaman (\%) pemberian Beauveria bassiana dan POC pengamatan intensitas kerusakan tanaman keong mas serta interaksinya memberikan disajikan pada tabel 5.

Tabel 5. Pengaruh Beauveria bassiana dan pupuk organik cair keong mas terhadap rata-rata intensitas kerusakan tanaman $(\%)$

\begin{tabular}{ccccc}
\hline Beauveria & \multicolumn{4}{c}{ POC keong mas $(\mathrm{p})$} \\
\cline { 2 - 5 } bassiana $(\mathrm{b})$ & $\mathrm{p}_{0}$ & $\mathrm{p}_{1}$ & $\mathrm{p}_{2}$ & Rata-rata \\
\hline $\mathrm{b}_{0}$ & 35,00 & 30,00 & 26,67 & 30,56 \\
$\mathrm{~b}_{1}$ & 21,67 & 20,00 & 8,33 & 16,67 \\
$\mathrm{~b}_{2}$ & 15,00 & 13,33 & 11,67 & 13,33 \\
\hline Rata-rata & 23,89 & 21,11 & 15,56 & \\
\hline
\end{tabular}

Keterangan: $\mathrm{b}_{0}=$ kontrol, $\mathrm{b}_{1}=20 \mathrm{~g}$ Beauveria bassiana $\mathrm{l}^{-1}$ air, $\mathrm{b}_{2}=40 \mathrm{~g}$ Beauveria bassiana $\mathrm{l}^{-1}$

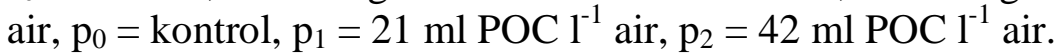

Hasil penelitian menunjukkan bahwa Beauveria bassiana memberikan pengaruh tidak nyata terhadap semua parameter yaitu jumlah buah per tanaman, bobot per buah, hasil per tanaman, hasil produksi per hektar, dan intensitas kerusakan tanaman. Hal ini sesuai dengan penelitian Hasibuan dkk. (2014) yang menyatakan bahwa pemberian Beauveria bassiana berpengaruh tidak nyata terhadap tinggi tanaman, jumlah daun, jumlah bunga, dan jumlah polong tanaman kedelai. Menurut Purnama dkk. (2015), Beauveria bassiana termasuk jamur enthomopatogen, yang artinya dapat menginfeksi bahkan menimbulkan kematian pada serangga. Intarti dkk. (2020) menambahkan bahwa jamur Beauveria bassiana juga merupakan parasit agresif untuk berbagai jenis serangga dan menyerang baik pada tahapan larva maupun usia dewasa sehingga jamur ini tidak berpengaruh terhadap pertumbuhan dan hasil.

Semua parameter pertumbuhan dan hasil terung pada penelitian ini berpengaruh tidak nyata terhadap pemberian Beauveria bassiana. Hal ini sesuai hasil penelitian Mandasari dkk. (2015) bahwa pemberian B. bassiana tidak memberikan pengaruh terhadap pertumbuhan pada fase vegetatif dan generatif dikarenakan 
jamur $B$. bassiana merupakan mikroorganisme saprofit (tidak memiliki klorofil dan hidup pada hasil perombakan atau pelapukan jasad lain), serta hidup menempel atau menjadi parasit pada serangga sasarannya saja sehingga tidak mempengaruhi pertumbuhan tanaman.

pemberian $B$. bassiana memberikan pengaruh tidak nyata terhadap semua parameter pengamatan, tetapi didapatkan ratarata hasil produksi per hektar $\left(\mathrm{t} \mathrm{ha}^{-1}\right)$ tertinggi pada perlakuan $\mathrm{b}_{2}\left(40 \mathrm{~g}\right.$ Beauveria bassiana $\mathrm{l}^{-1}$ air) yaitu sebesar 13,62 $\mathrm{t} \mathrm{ha}^{-1}$. Sedangkan hasil terendah diperoleh pada perlakuan $\mathrm{b}_{0}$ (tanpa perlakuan $B$. bassiana) yaitu sebesar $12,98 \mathrm{t}$ $\mathrm{ha}^{-1}$.

Hasil analisis menunjukkan bahwa pemberian $B$. bassiana juga berpengaruh tidak nyata terhadap intensitas kerusakan tanaman. Hal ini diduga bahwa tanaman terung varietas Laguna F1 memiliki ketahanan terhadap serangan hama dan penyakit. Walaupun pemberian $B$. bassiana berpengaruh tidak nyata, tetapi terjadi kecenderungan penurunan intensitas kerusakan tanaman dengan dilakukan peningkatan konsentrasi $B$. bassiana. Berdasarkan hasil penelitian, intensitas kerusakan tanaman tanpa pemberian B. bassiana $\left(\mathrm{b}_{0}\right)$, pemberian $20 \mathrm{~g}$ B. bassiana $\mathrm{l}^{-1}$ air $\left(\mathrm{b}_{1}\right), 40 \mathrm{~g} B$. bassiana $\mathrm{l}^{-1}$ air $\left(\mathrm{b}_{2}\right)$ berturut-turut yaitu sebesar $30,56 \%, 16,67 \%$, dan $13,33 \%$. Tanaman tanpa pemberian $B$. bassiana menjadi lebih rentan dibandingkan tanaman berperlakuan B. bassiana (Gambar 1 dan 2).

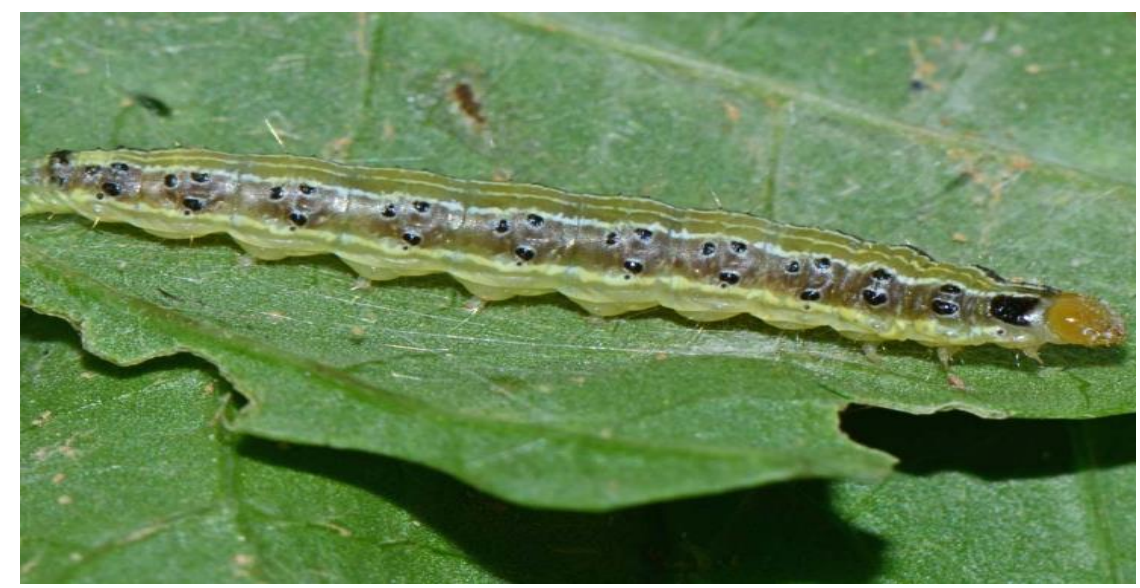

Gambar 1. Serangan ulat grayak pada tanaman terung tanpa perlakuan Beauveria bassiana

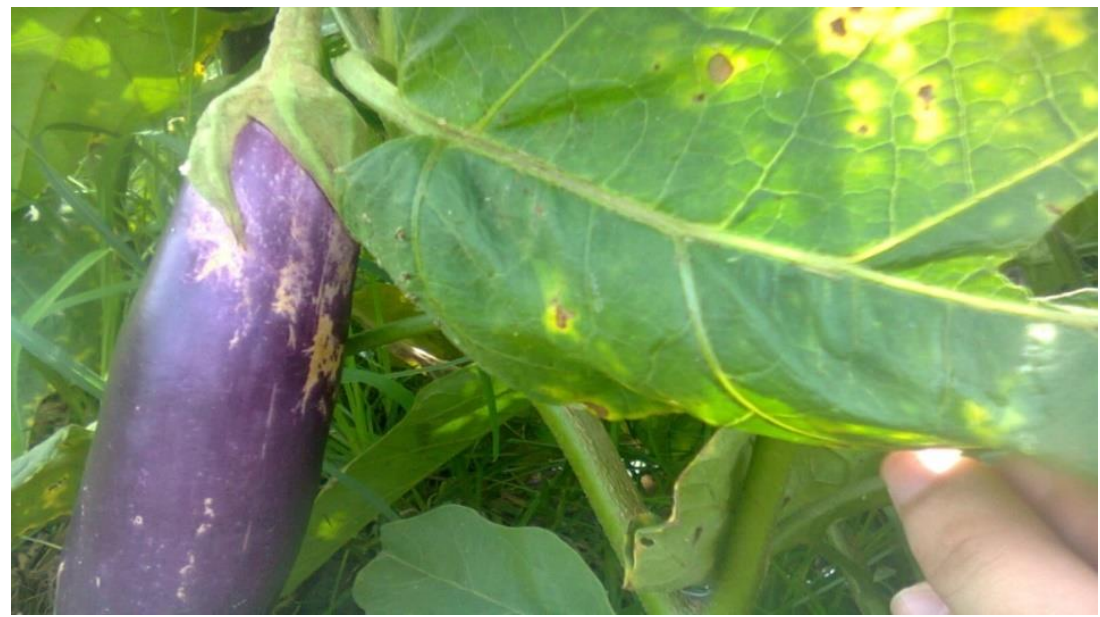

Gambar 2. Tanaman terung tanpa perlakuan Beauveria bassiana yang terserang penyakit bercak daun 
Hal ini sesuai dengan pendapat Tantawizal dkk. (2015) bahwa semakin tinggi konsentrasi yang diaplikasikan, maka kerapatan konidia jamur $B$. bassiana semakin tinggi, sehingga kemungkinan konidia yang menempel pada tubuh serangga semakin banyak yang mengakibatkan penetrasi ke tubuh serangga semakin cepat dan mengakibatkan jaringan tubuh serangga rusak. Gargita et al., (2017) menambahkan bahwa semakin pekat konsentrasi $B$. bassiana maka akan semakin banyak kerapatan spora di dalamnya, sehingga kemungkinan serangga akan terinfeksi semakin besar.

\section{Pengaruh POC Keong Mas}

Pemberian POC keong mas berpengaruh tidak nyata terhadap semua parameter pengamatan yaitu jumlah buah per tanaman, bobot per buah, hasil per tanaman, hasil produksi per hektar, dan intensitas kerusakan tanaman. Hasil yang tidak berpengaruh nyata ini diduga karena sifat pupuk organik seperti
POC keong mas yang lambat terurai sehingga tidak bisa terserap tanaman secara sempurna. Hal ini sesuai dengan pernyataan Rahman (2014), bahwa, pupuk organik bersifat slow release. sehingga respon tanaman terhadap pupuk organik lebih lambat.

Beberapa kandungan senyawa pada POC mudah menguap seperti senyawa amoniak. Amoniak juga mudah mengalami pencucian oleh air hujan, oleh karena itu hanya sebagian kecil unsur hara $\mathrm{N}$ yang dapat diserap oleh tanaman sehingga menyebabkan berpengaruh tidak nyata. Hal ini diperkuat oleh pernyataan Nugroho dkk. (2019), bahwa POC mudah menguap (ammonia) dan mudah tercuci oleh air hujan, sehingga hanya sedikit yang terserap untuk memenuhi kebutuhan tanaman.

Hasil analisis tanah sebelum penelitian menunjukkan bahwa $\mathrm{pH}$ tanah yaitu 5,20. Sesuai dengan pernyataan Siswanto (2006), $\mathrm{pH}$ sebesar 5,20 tergolong kategori masam (Tabel 6).

Tabel 6. Kategori pH tanah

\begin{tabular}{lcccccc}
\hline Parameter & $\begin{array}{c}\text { Sangat } \\
\text { masam }\end{array}$ & Masam & $\begin{array}{c}\text { Agak } \\
\text { masam }\end{array}$ & Netral & $\begin{array}{c}\text { Agak } \\
\text { alkalis }\end{array}$ & Alkalis \\
\hline $\mathrm{pH}\left(\mathrm{H}_{2} \mathrm{O}\right)$ & $<4,5$ & $4,5-5,5$ & $5,6-6,5$ & $6,6-7,5$ & $7,6-8,5$ & $>8,5$ \\
\hline
\end{tabular}

Menurut Darlita dkk. (2017), rendahnya $\mathrm{pH}$ tanah akan menyebabkan menurunnya ketersediaan hara bagi tanaman yang pada akhirnya akan menurunkan produksi tanaman. Rendahnya $\mathrm{pH}$ tanah yang menyebabkan kation asam seperti Al bersifat mobile. Pada tanah masam, kandungan unsur mikro seperti seng $(\mathrm{Zn})$, tembaga $(\mathrm{Cu})$, dan kobalt $(\mathrm{Co})$ juga tinggi sehingga meracuni tanaman.

Pemberian POC keong mas memberikan pengaruh tidak nyata terhadap semua parameter pengamatan, tetapi didapatkan ratarata hasil produksi per hektar $\left(\mathrm{t} \mathrm{ha}^{-1}\right)$ tertinggi pada perlakuan $\mathrm{p}_{2}\left(42 \mathrm{ml}\right.$ POC $\mathrm{l}^{-1}$ air $)$ yaitu sebesar 14,27 t ha ${ }^{-1}$. Sedangkan hasil terendah diperoleh pada perlakuan $\mathrm{p}_{0}$ (tanpa perlakuan POC keong mas) yaitu sebesar 11,92 $\mathrm{t} \mathrm{ha}^{-1}$. Rata-rata intensitas kerusakan tanaman tertinggi diperoleh pada perlakuan $\mathrm{p}_{0}$ (tanpa perlakuan POC keong mas) yaitu sebesar $23,89 \%$, sedangkan hasil terendah diperoleh pada perlakuan $\mathrm{p}_{2}\left(42 \mathrm{ml}\right.$ POC $\mathrm{l}^{-1}$ air $)$ yaitu sebesar $15,56 \%$.

\section{Interaksi antara Beauveria bassiana dan POC Keong Mas}

Berdasarkan hasil semua sidik ragam, interaksi antara Beauveria bassiana dan POC keong mas memberikan pengaruh tidak nyata terhadap semua parameter pengamatan. Pengaruh yang tidak nyata menunjukkan bahwa tidak adanya aktivitas yang saling mendukung antara $B$. bassiana dan POC keong mas atau kedua faktor perlakuan tersebut masih memberikan pengaruh sendiri-sendiri. Menurut Mukhlisin (2010), jika interaksi tidak berpengaruh nyata maka penyerapan dilakukan secara terpisah atau salah satunya saja, hal ini 
menunjukkan bahwa fungsi kedua faktor tidak saling mempengaruhi.

Diketahui bahwa masing-masing faktor perlakuan tersebut mempunyai fungsi dan manfaat yang berbeda bagi tanaman. Menurut Rosmiati dkk. (2018), B. bassiana merupakan agens pengendali hayati yang sangat efektif mengendalikan sejumlah spesies serangga dari ordo Coleoptera, Lepidoptera, Hemiptera, Homoptera, Orthoptera, dan Diptera. Sedangkan menurut Imma (2011), POC mempunyai manfaat merangsang pertumbuhan tunas baru, memperkuat tangkai serbuk sari, memperbaiki klorofil pada daun, memperbaiki sistem jaringan sel dan memperbaiki sel-sel rusak pada tanaman, dan merangsang pertumbuhan kuncup bunga.

Walaupun interaksi antara $B$. bassiana dan POC keong mas berpengaruh tidak nyata terhadap semua parameter pengamatan, tetapi didapatkan rata-rata hasil produksi per hektar $\left(\mathrm{t} \mathrm{ha}^{-1}\right.$ ) tertinggi pada kombinasi perlakuan $\mathrm{b}_{1} \mathrm{p}_{2}\left(20 \mathrm{~g}\right.$ Beauveria bassiana $\mathrm{l}^{-1}$ air dan $42 \mathrm{ml}$ POC $\mathrm{l}^{-1}$ air) yaitu sebesar 15,07 $\mathrm{t} \mathrm{ha}^{-1}$. Sedangkan hasil terendah diperoleh pada kombinasi perlakuan $b_{1} p_{0}(20 \mathrm{~g}$ Beauveria bassiana $1^{-1}$ air dan tanpa perlakuan POC keong mas) yaitu sebesar 11,56 $\mathrm{t} \mathrm{ha}^{-1}$. Ratarata intensitas kerusakan tanaman tertinggi diperoleh pada kombinasi perlakuan $b_{0} p_{0}$ (tanpa perlakuan $B$. bassiana dan tanpa perlakuan POC keong mas) yaitu 35,00\% dan rata-rata terendah pada kombinasi perlakuan $\mathrm{b}_{1} \mathrm{p}_{2}\left(20 \mathrm{~g}\right.$ Beauveria bassiana $\mathrm{l}^{-1}$ air dan $42 \mathrm{ml}$ POC $1^{-1}$ air) yaitu $8,33 \%$.

\section{KESIMPULAN DAN SARAN}

\section{Kesimpulan}

Hasil penelitian yang telah dilakukan tentang pengaruh Beauveria bassiana dan POC keong mas terhadap pertumbuhan dan hasil terung maka dapat disimpulkan bahwa pemberian Beauveria bassiana memberikan pengaruh tidak nyata terhadap semua parameter pengamatan. Rata-rata hasil produksi per hektar $\left(\mathrm{t} \mathrm{ha}^{-1}\right)$ tertinggi diperoleh pada perlakuan $\mathrm{b}_{2}\left(40 \mathrm{~g}\right.$ Beauveria bassiana $^{-1}$ air) yaitu $13,62 \mathrm{t} \mathrm{ha}^{-1}$ dan rata-rata terendah pada perlakuan $b_{0}$ (tanpa perlakuan) yaitu $12,98 \mathrm{t} \mathrm{ha}^{-1}$. Rata-rata intensitas kerusakan tanaman tertinggi diperoleh pada perlakuan $b_{0}$ (tanpa perlakuan) yaitu $30,56 \%$ dan rata-rata terendah pada perlakuan $b_{2}(40 \mathrm{~g}$ Beauveria bassiana $1^{-1}$ air) yaitu $13,33 \%$.

Pemberian POC keong mas memberikan pengaruh tidak nyata terhadap semua parameter pengamatan. Rata-rata hasil produksi per hektar $\left(\mathrm{t} \mathrm{ha}^{-1}\right)$ tertinggi diperoleh pada perlakuan $\mathrm{p}_{2}\left(42 \mathrm{ml} \mathrm{POC} \mathrm{l}^{-1}\right.$ air $)$ yaitu $14,27 \mathrm{t} \mathrm{ha}^{-1}$ dan rata-rata terendah pada perlakuan $\mathrm{p}_{0}$ (tanpa perlakuan) yaitu $11,92 \mathrm{t}$ $\mathrm{ha}^{-1}$. Rata-rata intensitas kerusakan tanaman tertinggi diperoleh pada perlakuan $\mathrm{p}_{0}$ (tanpa perlakuan) yaitu $23,89 \%$ dan rata-rata terendah pada perlakuan $\mathrm{p}_{2}\left(42 \mathrm{ml} \mathrm{POC} \mathrm{l}^{-1}\right.$ air $)$ yaitu $15,56 \%$.

Interaksi antara Beauveria bassiana dan POC keong mas memberikan pengaruh tidak nyata terhadap semua parameter pengamatan. Rata-rata hasil produksi per hektar $\left(\mathrm{t} \mathrm{ha}^{-1}\right)$ tertinggi diperoleh pada kombinasi perlakuan $\mathrm{b}_{1} \mathrm{p}_{2}\left(20 \mathrm{~g}\right.$ Beauveria bassiana $\mathrm{l}^{-1}$ air dan $42 \mathrm{ml}$ POC $1^{-1}$ air) yaitu $15,07 \mathrm{t} \mathrm{ha}^{-1}$ dan rata-rata terendah pada kombinasi perlakuan $\mathrm{b}_{1} \mathrm{p}_{0}(20 \mathrm{~g}$ Beauveria bassiana $1^{-1}$ air dan tanpa perlakuan POC keong mas) yaitu 11,56 $\mathrm{t} \mathrm{ha}^{-1}$. Rata-rata intensitas kerusakan tanaman tertinggi diperoleh pada kombinasi perlakuan $b_{0} p_{0}$ (tanpa perlakuan $B$. bassiana dan tanpa perlakuan POC keong mas) yaitu 35,00\% dan rata-rata terendah pada kombinasi perlakuan $\mathrm{b}_{1} \mathrm{p}_{2}\left(20 \mathrm{~g}\right.$ Beauveria bassiana $\mathrm{l}^{-1}$ air dan $42 \mathrm{ml}$ POC $1^{-1}$ air) yaitu $8,33 \%$.

\section{Saran}

Setelah dilakukan penelitian dapat dikemukakan saran yaitu pemberian $20 \mathrm{~g}$

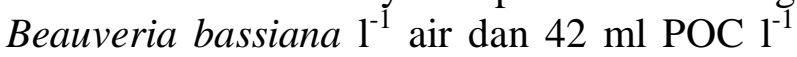
air dapat dianjurkan karena memberikan hasil terbaik. Selain itu, perlu dilakukan penelitian lebih lanjut terkait konsentrasi pemberian Beauveria bassiana dan POC keong mas sehingga diperoleh hasil yang berpengaruh nyata. 


\section{DAFTAR PUSTAKA}

Asrah, A., dan Novriani. 2019. Pemanfaatan keong mas sebagai pupuk organik cair yang dikombinasikan dengan pupuk nitrogen dalam mendukung pertumbuhan dan produksi tanaman selada (Lactuca sativa L.). Klorofil: Jurnal Ilmu-Ilmu Agroteknologi. 14(2): 83-89.

Bednarek, A., E. Popowska-Nowak, E. Pezowicz, and M. Kamionek. 2004. Integratedmethods in pest control: effect ofinsecticides on entomopathogenic fungi (Beauveria bassiana (Bals.) Vuill., B. brongniartii (Sacc.)), and nematodes (Heterorhabditis megidis Poinar, Jackson, Klein, Steinernema feltiae Filipjev, S. glaseri Steiner). Polish Journal of Ecology 52 (2): 223-228.

Cahyono, B. 2016. Untung besar dari terung hibrida. Pustaka Mina, Jakarta.

Darlita, R.R., B. Joy, dan R. Sudirja. 2017. Analisis beberapa sifat kimia tanah terhadap peningkatan produksi kelapa sawit pada tanah pasir di Perkebunan Kelapa Sawit Selangkun. Program Studi Ilmu Tanah, Fakultas Pertanian, Universitas Padjajaran. Jurnal Agrikultura. 28 (1): 15-20.

Dinas Pertanian dan Peternakan Kabupaten Kutai Kartanegara. 2020. Laporan Tahunan 2018 dan 2019. Dinas Pertanian dan Peternakan Kabupaten Kutai Kartanegara, Tenggarong.

Gargita, I., I. Sudiarta, dan G. Wirya. 2017. Pemanfaatan patogen serangga (Beauveria bassiana Bals.) untuk mengendalikan hama penghisap buah kakao (Helopeltis spp.) di Desa Gadungan, Kecamatan Selemadeg Timur, Kabupaten Tabanan. E-Jurnal
Agroekoteknologi Tropika. 6(1): 1120.

Hasibuan, S. 2014. Respon pemberian konsentrasi pupuk Herbafarm dan POC keong mas terhadap pertumbuhan dan produksi tanaman mentimun (Cucumis sativus L.). Universitas Sumatera Utara, Medan.

Imma. 2011. Pupuk organik cair. Dikunjungi 10 Agustus 2020. <http://pupukorganik-

cairkhtimahta.blogspot.com/2011/10/bl ogspot-post.html/m=1>.

Intarti, D.Y., I. Kurniasari, dan A. Sudjianto. 2020. Efektivitas agen hayati Beauveria bassiana dalam menekan hama Thrips sp. Pada tanaman Cabai Rawit (Capcisum frustescens L.). Agrovigor. 13 (1): 10-15.

Mandasari, L.F., R. Hasibuan, A.M. Hariri, Purnomo. 2015. Pengaruh frekuensi aplikasi isolat jamur entomopatogen Beauveria bassiana terhadap kutu daun (Aphis glycines Matsumura) dan organisme nontarget pada pertanaman kedelai. Agrotek Tropika. 3(3): 384392.

Mukhlisin. 2010. Pengaruh phonska terhadap pertumbuhan dan hasil cabai besar (Capsicum annum L.). Skripsi. Program Sarjana. Universitas Kutai Kartanegara.

Ngadiani, D.K. Binawati, V. Andriani. 2021. Pengaruh pupuk organik cair keong mas (Pomacea canaliculata L.) dan Paklobutrazol terhadap pertumbuhan padi var. Mapan P-05. J. Agrotek Tropika. 9(1): 113-120.

Nugroho, C.C., Karno, Supriyono. 2020. Efektivitas pupuk organik cair keong mas terhadap pertumbuhan dan hasil 
padi varietas Ciherang. Jurnal Magrobis. 20(2): 203-214.

Nugroho, C.C., Sundari, A.H. Asabah. 2019. Studi pertumbuhan okulasi bibit Lai (Durio kutejensis HASSK. BECC) varietas Mahakam. Ziraa'ah. 44(2): 217-225.

Poerba, A., R. Situmerang, L.R. Sinaga. 2019. Pengaruh pemberian pupuk organik cair keong mas (Pomacea canaliculata) dan penggunaan mulsa plastik hitam perak terhadap pertumbuhan dan hasil tanaman terung ungu (Solanum melongena L.). Jurnal Ilmiah Rhizobia. 1(1): 1-15.

Purnama, H., N. Hidayati, dan E. Setyowati. 2015. Pengembangan produksi pestisida alami dari Beauveria bassiana dan Trichoderma sp. menuju pertanian organik. Warta. 18 (1): 1-9.

Rahman, D.T. 2014. Unsur hara makro dan mikro yang dibutuhkan oleh tanaman. Dikunjungi $\quad 10 \quad$ Agustus 2020.<https://organices.co.id/2014/05/ 03/unsur-makro-dan-mikro-yangdibutuhkan-oleh-tanaman/>.

Rosmiati, A., C. Hidayat, E. Firmansyah, dan Y. Setiati. 2018. Potensi Beauveria bassiana sebagai agens hayati Spodoptera litura Fabr. pada tanaman kedelai. J. Agrikultura. 29 (1): 43-47.

Sembel D.T., E. M. Meray., M. M. Ratulangi., C. S. Rante., dan M. F. Dien, 2007. Activities in North Sulawesi.
Kerjasama Fakultas Pertanian Universitas Sam Ratulangi dengan Clemson University/Virginia Tech/USAID. IPM /CRSP. Workshop, Ciloto, Bogor July 2007.

Sheeba, G., S. Seshadri, N. Raja, S. Janarthanan, and S. Ignacimutu. 2001. Efficacy of Beauveria bassiana for control of the riceweevil Sitophilus oryzae (L.) (Coleoptera: Curculionidae). Appl. Entomol. Zool. 36 (1): 117-120.

Siswanto. 2006. Evaluasi sumber daya lahan. Penerbit UPN Press. Surabaya.

Tantawizal, A. Inayati, dan Y. Prayogo. 2015. Potensi cendawan entomopatogen Beauveria bassiana (Balsamo) Vuillemin untuk mengendalikan hama boleng Cylas formicarius F. pada tanaman ubi jalar. Buletin Palawija. 29: $46-53$.

Thungrabeab, M. and S. Tongma. 2007. Effect ofentomopathogenic fungi, Beauveriabassiana (Balsamo) and Metarhiziumanisopliae (Metsch) on non targetinsects. KMITL Sci. Tech. J. 7 (S1): 8-12.

Townsend, R.J., M. O'Callaghan, V. W. Johnson, and T. A. Jackson. 2003. Compatibility of microbial control agents Serratiaentomophila and Beauveria bassiana withselected fertilizers. New Zealand PlantProtection 56: 118-122. 